\title{
Geochemical Characteristics of Amphibolites in Parts of Iseyin-Oyan Schist Belt, Southwestern Nigeria
}

\author{
Maryam O. Abdus-Salam, Anthony T. Bolarinwa, Akinade S. Olatunji and Victoria Omotunde
}

\section{ABSTRACT}

\begin{abstract}
Amphibolite is an important lithologic unit of the Nigerian basement complex that are commonly intercalated within metasedimentary sequences. Disseminated grains of sulphide minerals and base metal deposits are reported to occur in amphibolites and some other lithologies in other schist belts of Nigeria apart from the Iseyin-Oyan schist belt. Detailed geochemical study of amphibolitic rocks in this schist belt is scarce in literature, whereas none exist for the area under study, thus, this study is aimed at delineating the amphibolites within the Iseyin-Oyan schist belt around Itasa area with detail appraisal of their petrography and geochemical characteristics. A geologic field mapping was undertaken, and fresh representative amphibolite samples were obtained. Petrographic and geochemical studies of the samples were carried out with a view to understand their nature and petrogenetic characteristics. Geochemical data were elucidated using diverse geochemical discrimination diagrams. The amphibolites occur as lenses of small to large rocky boulders trending NNE-SSW and are essentially basal to quartz mica schist. Modal compositions revealed that they are dominantly composed of hornblende and plagioclase. XRD and mineral chemistry revealed that the plagioclase ranged from andesine to anorthite while hornblende is mainly magnesiohornblende. Geochemical data and discrimination diagrams revealed that the amphibolites are formed from basaltic to basaltic-andesite protolith that are of tholeiitic nature and had suffered crustal contamination. Tectonic discrimination diagrams indicated that the rocks were emplaced in the Mid Ocean Ridge but had been affected by collision due to Pan African Orogenic tectonic event.
\end{abstract}

Keywords: Amphibolites, Crustal contamination, Geochemical characteristics, Iseyin-Oyan schist belt.

\section{INTRODUCTION}

The Nigerian basement complex constitutes the most extensive assemblage of the Trans-Saharan mobile belt interposed between the cratons of West Africa and Congo (Fig. 1) [1]. Petro-lithologic groups within the Basement include the migmatite -gneisses quartzite complex, the schist belt, the Pan African Older granites and the Undeformed dykes [2]-[5]. A number of north- southerly trending Proterozoic rocks, the schist belts, occur more prominently within the western part of the basement. They are lowmedium grade supracrustal rocks which are composed of lithologies including marbles, calc-gneisses, psammites and mafic-ultramafic units dominated by amphibolite. These schist belts include Iseyin-Oyan, Maru, Anka, Zuru, Kazaure, Kushaka, Igarra, Wonaka, Karaukarau, Zungeru-Birnin Gwari and Ilesha [6].

There are little records of detailed geological investigation carried out on various units of the Precambrian Basement Complex in the Iseyin-Oyan Schist Belt compared to other schist belts in Nigeria. Most of the rocks are generally
Published Online: October 30, 2020

ISSN: $2684-446 \mathrm{X}$

DOI :10.24018/ejgeo.2020.1.5.77

Maryam O. Abdus-Salam *

Department of Geosciences, Pan African University of Life and Earth Sciences Institute, University of Ibadan, Nigeria.

Department of Geology, The Polytechnic, Ibadan, Nigeria.

(e-mail: maryamakinsanya ${ }^{\circledR}$ gmail.com)

Anthony T. Bolarinwa

Department of Geology, University of Ibadan, Nigeria.

(e-mail: atbola@yoahoo.com)

\section{Akinade S. Olatunji}

Department of Geology, University of Ibadan, Nigeria.

(e-mail: akinadeshadrach@ ${ }^{@ m a i l . c o m) ~}$

Victoria B. Omotunde

Department of Geosciences, Pan African University of Life and Earth Sciences Institute, University of Ibadan, Nigeria.

(e-mail: vicomotunde@gmail.com)

*Corresponding Author described as undifferentiated schists and granites on the geological map of Nigeria [7] with no isolation of amphibolite lenses that dotted the area.

Amphibolites are important components of the Nigerian basement complex that are commonly found as ovoid-shaped bodies intercalated within metasedimentary sequences [8]. Disseminated grains of sulphide mineral and base metal deposits have been reported to occur in amphibolites and some other lithologic units in other schist belts of Nigeria [9] with the exception of Iseyin-Oyan schist belt. Furthermore, detailed geochemical study of these amphibolitic rocks in Iseyin-Oyan schist belt is scarce in literature. This study was therefore undertaken in order to delineate the amphibolites of the Iseyin-Oyan schist belt around the Itasa area, through detail appraisal of their geochemistry in order to understand their nature and petrogenetic characteristics. 


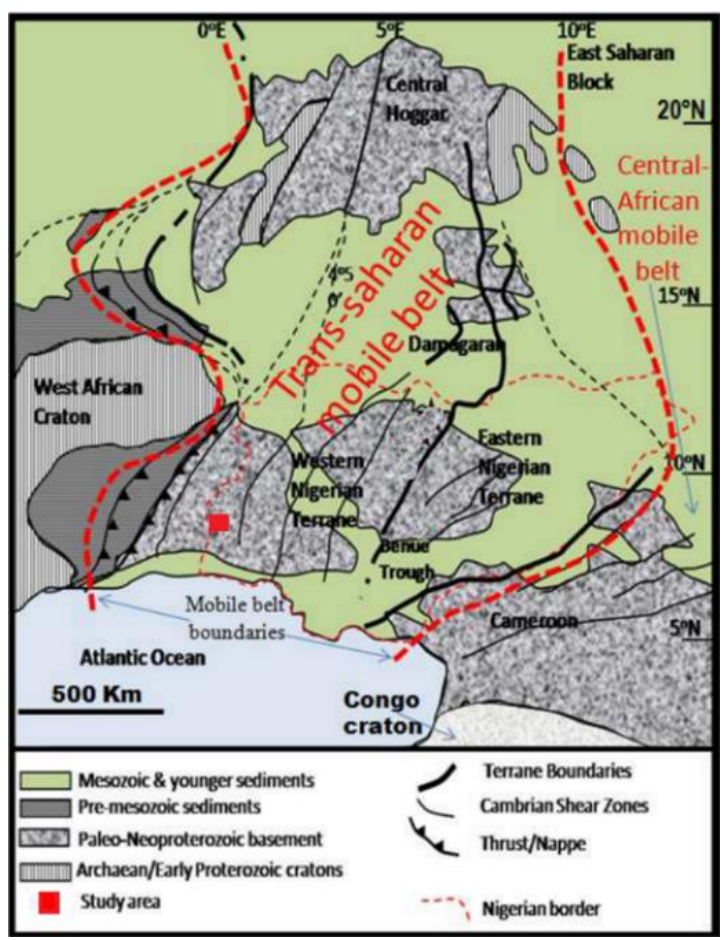

\section{STUDY LOCATION}

The study area lies within the Iseyin-Oyan schist belt, around Itasa area, southwestern part of Nigeria. The area includes villages like Ibudo Apata, Imadi and Idi Ero and delineated by latitude $8^{\circ} 00^{\prime}$ and $8^{\circ} 08^{\prime} \mathrm{N}$ and longitude $3^{\circ} 00^{\prime}$ and $3^{\circ} 07^{\prime} \mathrm{E}$. The area is characterized by rugged topography with elevations ranging from about 200 to about $500 \mathrm{~m}$. It is located within a tropical humid climate region with an annual temperature of $21^{\circ} \mathrm{C}$ and $34{ }^{\circ} \mathrm{C}$. The prevailing seasons are the Rainy (April to October) and the Dry Season (November to March). The average annual mean rainfall is $1,250 \mathrm{~mm}$ [10].

The exposed lithologies within the study area are quartz mica schist, amphibolite, granite gneiss, quartz diorite, biotite alkali granite and porphyritic granite (Fig. 2). The amphibolites, which are the focus of this study, trend NNESSW and occur in close association with the quartz mica schist. They are restricted to the western and central parts of the area.

Fig. 1. Regional geologic map showing the study area within the TransSaharan mobile Belt. (Modified after [1]).

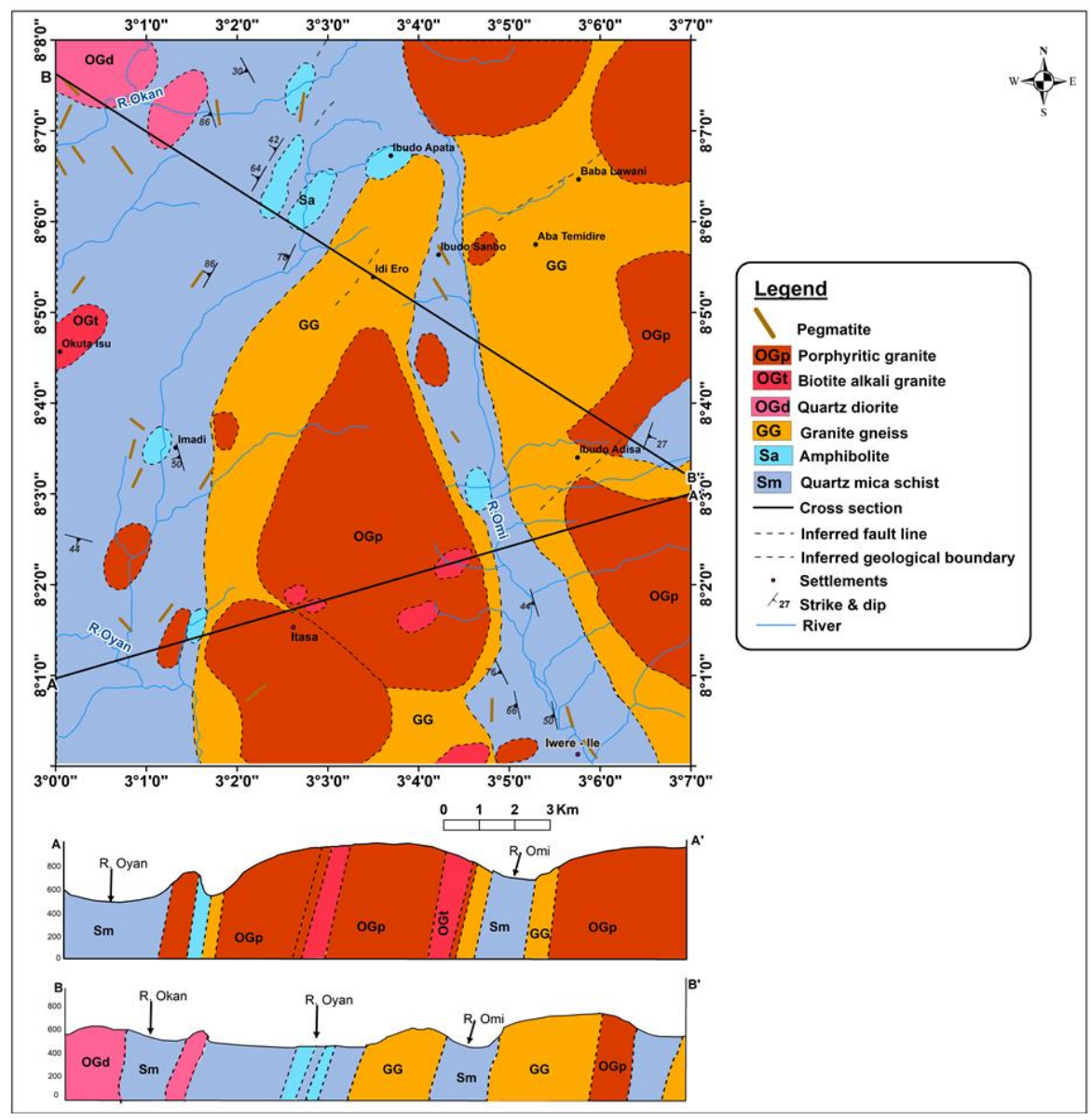

Fig. 2: Geological map of the study area (This study).

\section{METHODS}

Geological field mapping and collection of amphibolite samples were undertaken within the Iseyin-Oyan schist belt around Itasa area. Thin sections of the samples were prepared at the thin section laboratory of the Department of Geology, University of Ibadan, Nigeria. The thin sections were examined using binocular petrological microscope at the Department of Geology, The Polytechnic, Ibadan, Nigeria. Xray diffraction (XRD) analyses were conducted for the qualitative phase identification of the minerals within the amphibolite using PANalytical Empyrean X-ray Diffractometer with a graphite monochromated $\mathrm{Cu} \mathrm{Ka}$ radiation source operating at $40 \mathrm{kV}$ and $40 \mathrm{~mA}$ generating set 
over $5^{\circ}$ to $80^{\circ} 2 \theta$ angular range. Mineral chemistry of the essential and accessory minerals in the amphibolites were determined using a Scanning Electron Microscope (SEM) equipped with an Energy Dispersive Spectrometer that has an INCA 350 software and operating at $20-25 \mathrm{kV}$ accelerating voltage, 15-20 nA beam current and counting times of 20-35 s per element. Quantitative analysis of the major, trace and rare earth elements within amphibolites were determined using Xray Fluorescence spectroscopy (XRF) and Inductively Coupled Plasma Optical Emission Spectroscopy (ICP-OES) at the University of Wolverhampton, United Kingdom. Major oxides and trace elements concentrations were determined on powder pressed pellet using XRF
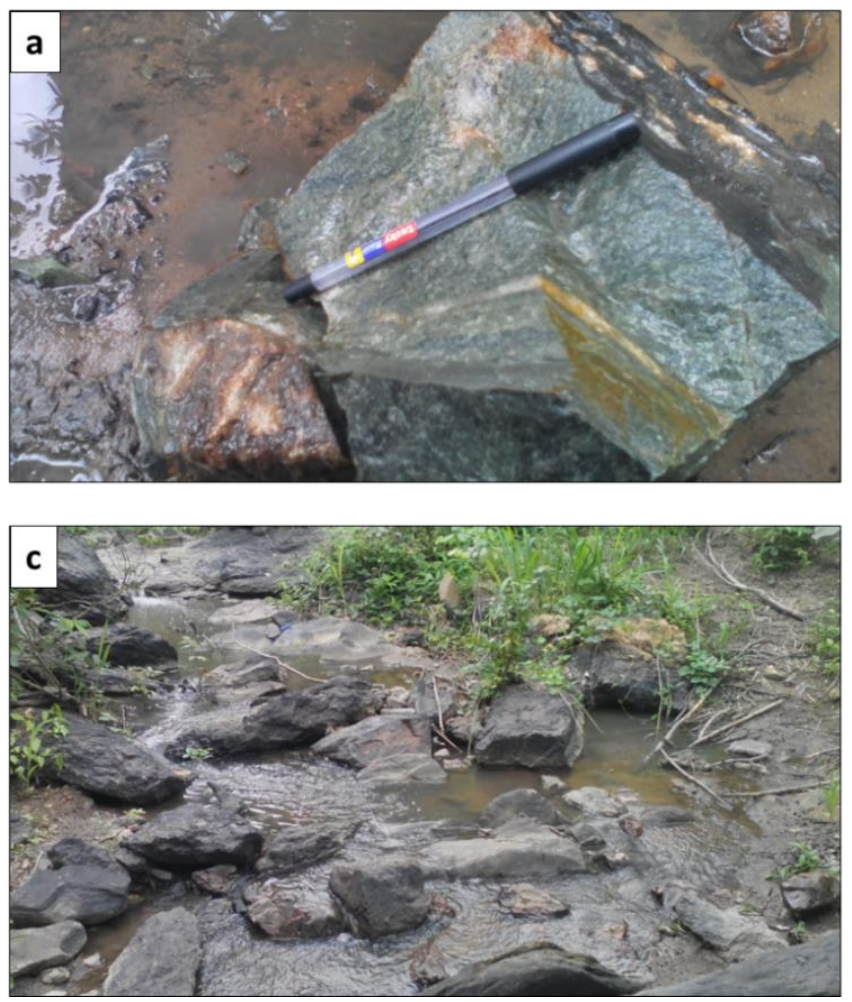

Fig. 3: Field photographs of amphibolites in the study area.

They are medium to coarse grained greenish rocks with modal compositions showing hornblende (40-55 vol.\%) and plagioclase (10-30 vol.\%) as the dominant minerals (Error! Reference source not found.). Other subordinate minerals include quartz (3 -6 vol.\%), epidote (0-11 vol.\%), titanite (2 to 9 vol. \%), biotite, zircon (0-1 vol. \%), apatite (0-1 vol. \%) and opaque minerals (0-1 vol. \%).

X- Ray diffractograms (Fig. 5) of the amphibolite is consistent with the petrographic information. Magnesiohornblende, anorthite, epidote, augite and quartz, were identified on the diffractograms. Based on the mineral paragenesis, the amphibolites reached amphibolite facies conditions.

Backscattered electron images of minerals in the amphibolite are shown in Fig. 6. Mineral chemistry revealed that hornblende is mainly magnesio-hornblende, which are subhedral to anhedral and have random or preferred orientations. It is pleochroic from red to brown and incorporates inclusions. The plagioclase ranged from andesine to anorthite composition and are characterised by albite twin lamella of narrow to broad bands indicating compositional variation. Zircon and apatite occur as whereas rare earth elements were analysed using ICPOES after sample digestion with fusion following the method described by Zhang et al [11].

\section{RESUlTS AND DISCUSSIONS}

\section{A. Petrography}

The amphibolites occur as lensoid bodies of small to large rocky boulders (Fig. 3) trending NNE-SSW. Field relationships show that they are essentially basal to quartz mica schist. They occur at the western and eastern parts of Itasa area, usually along river channels.
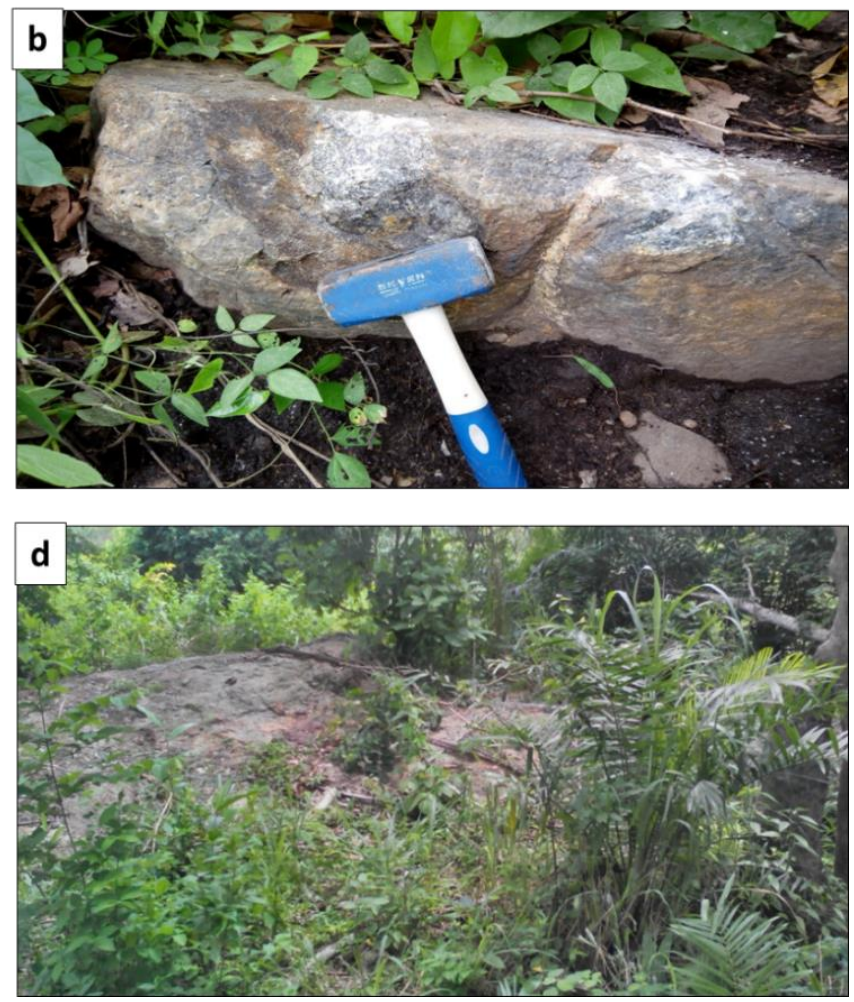

inclusions in magnesio-hornblende within the amphibolites. Opaque minerals are usually titanite, titanomagnetite and magnetite. Mineral alteration products include apatite and altered pyroxenes and amphiboles.

\section{B. Geochemistry}

Chemical compositions of the amphibolites (Table 1) revealed significant variation. The chemical data interpreted using the Niggli numbers suggested by Leake [12] indicated that the amphibolites are characteristic of mafic magmatic rocks. Positive correlation between $\mathrm{Cr}$ and $\mathrm{Ni}$ versus $\mathrm{mg}$ are typical of rocks formed from igneous progenitors [12]. However, low contents of $\mathrm{Ni}$ and $\mathrm{Cr}$ but high $\mathrm{Sr}, \mathrm{Ba}$ and $\mathrm{Zr}$ indicated that the amphibolites have crustal inputs [12]. Niggli discrimination diagrams (Fig. 7) revealed that they are mid-stage differentiated igneous rock with slight scattering confirming crustal input. 

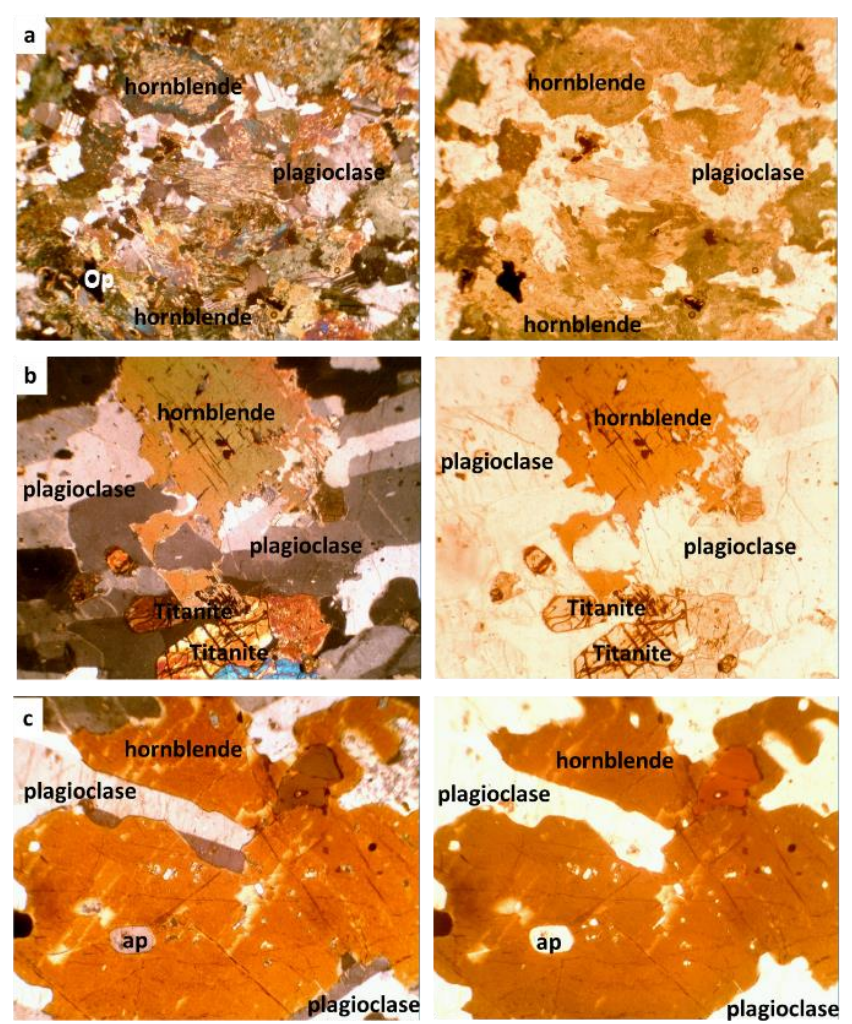

Fig. 4. Photomicrograph of amphibolites (Left: Cross Polarized light; and right: Plane polarised light) showing abundance of hornblende and plagioclase with minor titanite, apatite (ap) and opaque.
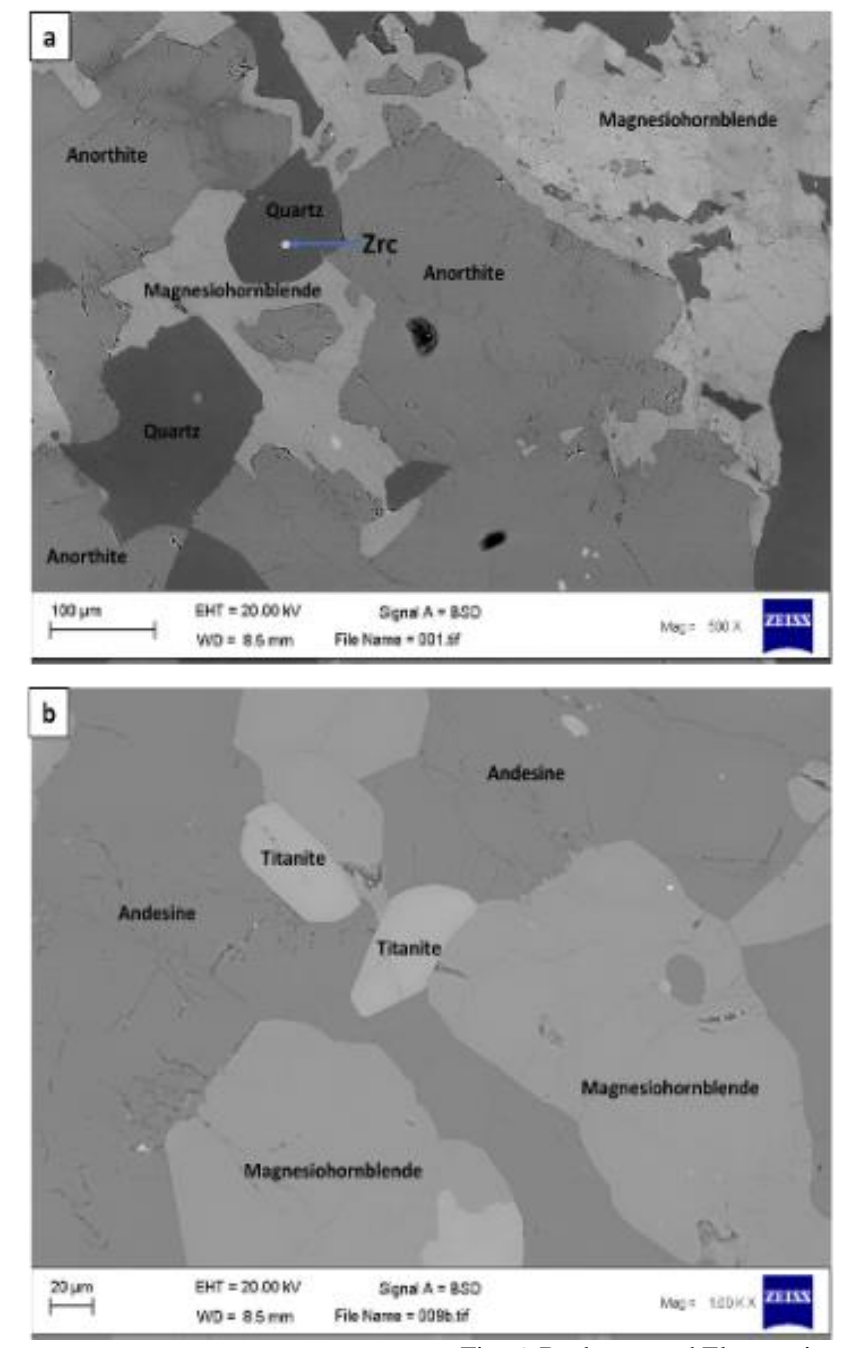

Fig. 6. Backscattered Electron images of the Amphibolites showing Anorthite.
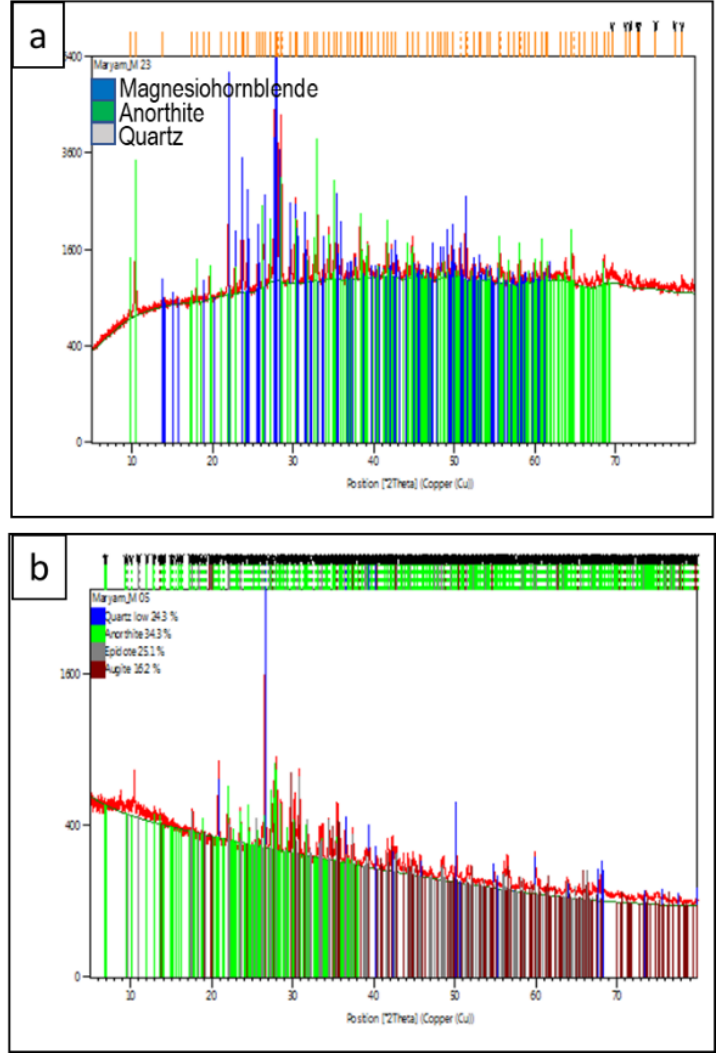

Fig. 5 X-ray diffractograms of the amphibolites under study.
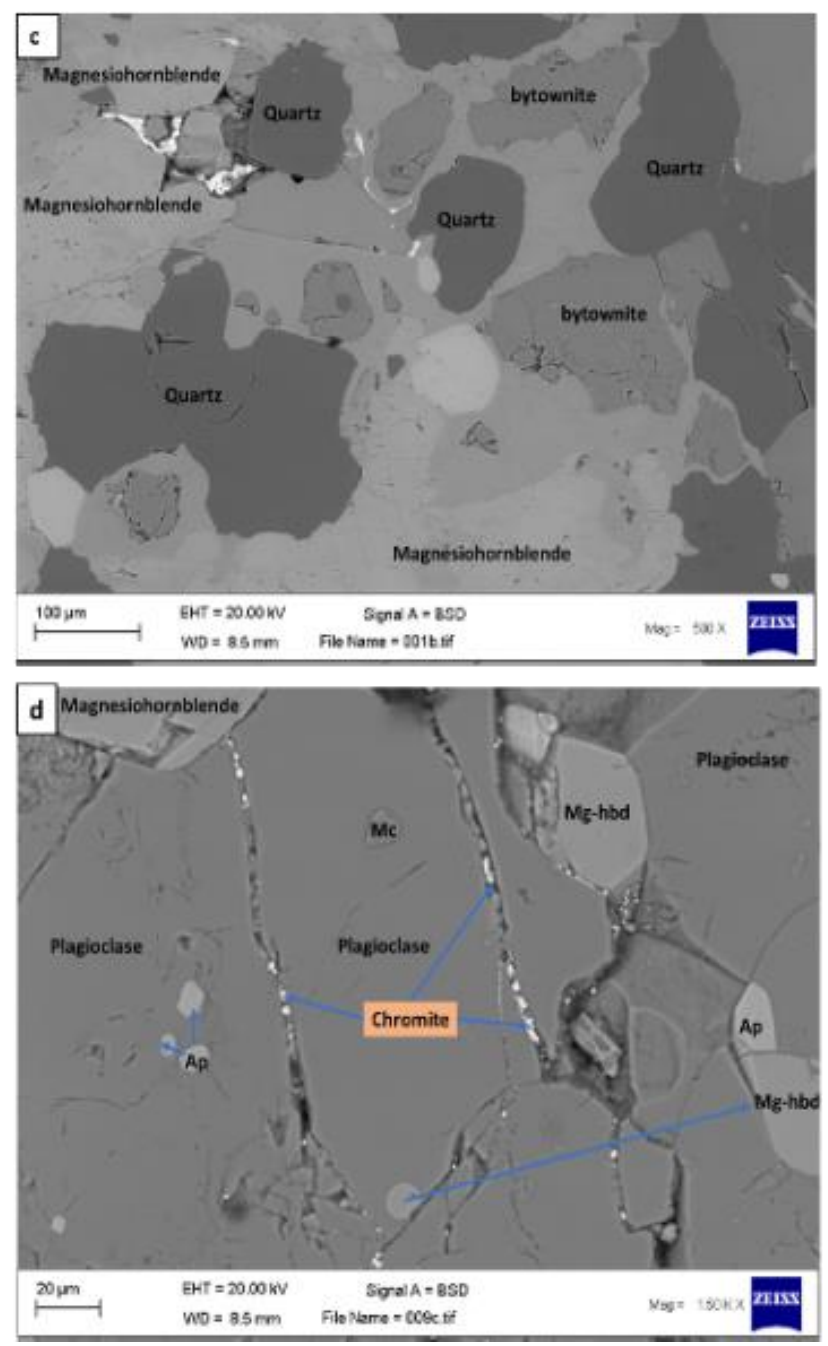
TABLE 1: MAJOR OXIDE (WT.\%), TRACE AND RARE EARTH ELEMENTS (PPM) CONCENTRATIONS IN THE AMPHIBOLITES OF THE STUDY AREA

\begin{tabular}{|c|c|c|c|c|}
\hline Oxides & Amph96 & Amph92 & Amph55 & Amph30 \\
\hline $\mathrm{SiO}_{2}$ & 53.75 & 53.46 & 49.24 & 53.77 \\
\hline $\mathrm{TiO}_{2}$ & 0.62 & 1.18 & 1 & 0.86 \\
\hline $\mathrm{Al}_{2} \mathrm{O}_{3}$ & 18.53 & 18.01 & 16.99 & 18.37 \\
\hline $\mathrm{Fe}_{2} \mathrm{O}_{3}$ & 7.06 & 7.35 & 10.23 & 8.2 \\
\hline $\mathrm{MnO}$ & 0.07 & 0.09 & 0.11 & 0.08 \\
\hline $\mathrm{MgO}$ & 2.56 & 3.7 & 5.92 & 4.19 \\
\hline $\mathrm{CaO}$ & 15.27 & 11.06 & 15.02 & 12.42 \\
\hline $\mathrm{Na}_{2} \mathrm{O}$ & 0.85 & 3.93 & 1.44 & 1.21 \\
\hline $\mathrm{K}_{2} \mathrm{O}$ & 0.03 & 0.4 & 0.53 & 0.29 \\
\hline $\mathrm{P}_{2} \mathrm{O}_{5}$ & 0.32 & 0.13 & 0.21 & 0.25 \\
\hline Total & 99.06 & 99.31 & 100.69 & 99.64 \\
\hline $\mathrm{Ba}$ & 381 & 320 & 350 & 331 \\
\hline $\mathrm{Cr}$ & 75 & 156 & 162 & 198 \\
\hline $\mathrm{Ni}$ & 46 & 77 & 39 & 87 \\
\hline V & 127 & 236 & 250 & 179 \\
\hline $\mathrm{Cu}$ & 14 & 31 & 14 & 16 \\
\hline $\mathrm{Nb}$ & 7 & 7 & 6 & 6 \\
\hline $\mathrm{Y}$ & 33 & 38 & 30 & 34 \\
\hline $\mathrm{Rb}$ & 10 & 14 & 24 & 13 \\
\hline $\mathrm{Sr}$ & 418 & 899 & 267 & 293 \\
\hline $\mathrm{Zr}$ & 120 & 205 & 113 & 136 \\
\hline $\mathrm{Zn}$ & 51 & 58 & 66 & 61 \\
\hline $\mathrm{Ga}$ & 19 & 22 & 18 & 21 \\
\hline $\mathrm{Sn}$ & 5 & 6 & 5 & 5 \\
\hline $\mathrm{Au}(\mathrm{ppb})$ & 1 & 3 & 1 & 1 \\
\hline As & 0 & 7 & 13 & 6 \\
\hline $\mathrm{Pb}$ & 1 & 5 & 5 & 3 \\
\hline Th & 9 & 8 & 9 & 8 \\
\hline $\mathrm{La}$ & 39.24 & 40.7 & 40.65 & 36.46 \\
\hline $\mathrm{Ce}$ & 75.58 & 81.18 & 84.2 & 70.4 \\
\hline $\operatorname{Pr}$ & 8.22 & 9.34 & 8.69 & 7.46 \\
\hline $\mathrm{Nd}$ & 28.91 & 28.46 & 24.66 & 21.67 \\
\hline $\mathrm{Sm}$ & 4.16 & 5.29 & 4.67 & 3.86 \\
\hline $\mathrm{Eu}$ & 1.03 & 1.16 & 1.12 & 1.03 \\
\hline $\mathrm{Gd}$ & 3.45 & 3.73 & 3.53 & 2.7 \\
\hline Dy & 3.24 & 3.22 & 2.85 & 3.2 \\
\hline $\mathrm{Er}$ & 2.08 & 2.41 & 1.9 & 2.23 \\
\hline $\mathrm{Tm}$ & 0.36 & 0.34 & 0.32 & 0.32 \\
\hline $\mathrm{Yb}$ & 2.07 & 2.41 & 1.99 & 2.22 \\
\hline $\mathrm{Lu}$ & 0.34 & 0.36 & 0.28 & 0.42 \\
\hline
\end{tabular}
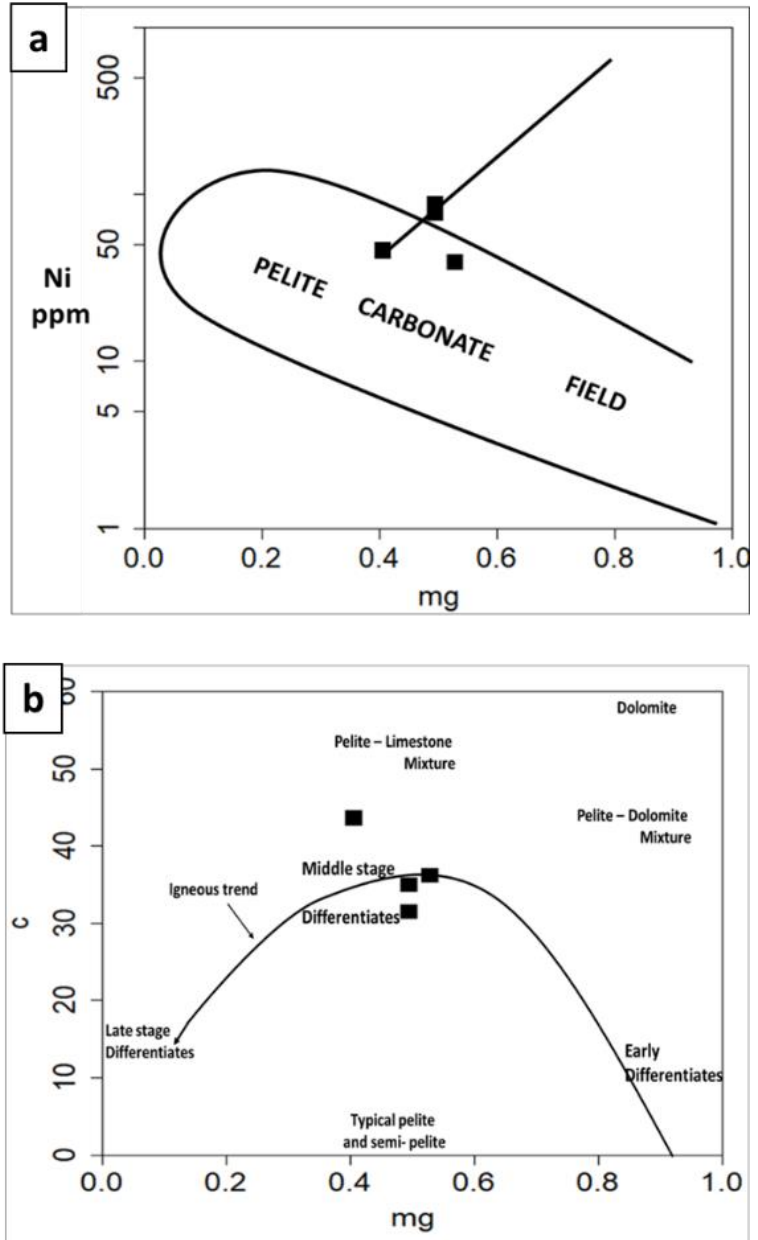

Fig. 7. Niggli variables and trace elements diagrams (a) Ni. versus Niggli mg: and (b) Niggli c vs. Niggli mg of the amphibolites showing igneous precursor with minor crustal input.

The protoliths of the amphibolites are basalt and basalticandesite (Fig. 8a-b) on the $\mathrm{Zr} / \mathrm{Ti}$ against $\mathrm{Nb} / \mathrm{Y}$ [13] diagrams; and the $\mathrm{Al}-\mathrm{Fe}^{\mathrm{T}}+\mathrm{Ti}-\mathrm{Mg}$ ternary plot [14].

The trace elements distribution intermediate between continental and oceanic basalts. The tholeiitic nature was confirmed on the [15] petrogenetic plot (Fig. 8c). Amphibolites with ocean floor affinity have been reported in Zuru schist belt [16], Obudu Plateau [17] and some of the IfeIlesha schist belt ( [18]. This contrasted continental tholeiites reported in another parts of Ilesha [8] and Guguruji schist belt [19]. Tholeiitic magma is characteristic of mafic volcanism in the Precambrian and occurred nearly to the exclusion of alkali basalts for the first three-quarters of geological time [20].

The chondrite [21]-normalized pattern (Fig. 8d)Error! Reference source not found. revealed a LREE > HREE trend which suggested possible crustal input. There is no apparent positive $\mathrm{Eu}$ anomaly suggestive of moderate plagioclase fractionation in the rocks and characteristics of basic rocks that have been granitized.

The $\mathrm{Zr}$ versus $\mathrm{Zr} / \mathrm{Y}$ diagram [22] and $\mathrm{Zr}-\mathrm{Nb}-\mathrm{Y}$ ternary plots [23] indicated that the amphibolite were emplaced between mid ocean ridge (divergent) and within continental plate and volcanic arc (divergent) settings (Fig. 9). These suggested that the protolith were mantle derived fractionated tholeiitic magma of mid oceanic character deposited in a back-arc environment and possibly got metamorphosed during the Pan-African orogeny. 

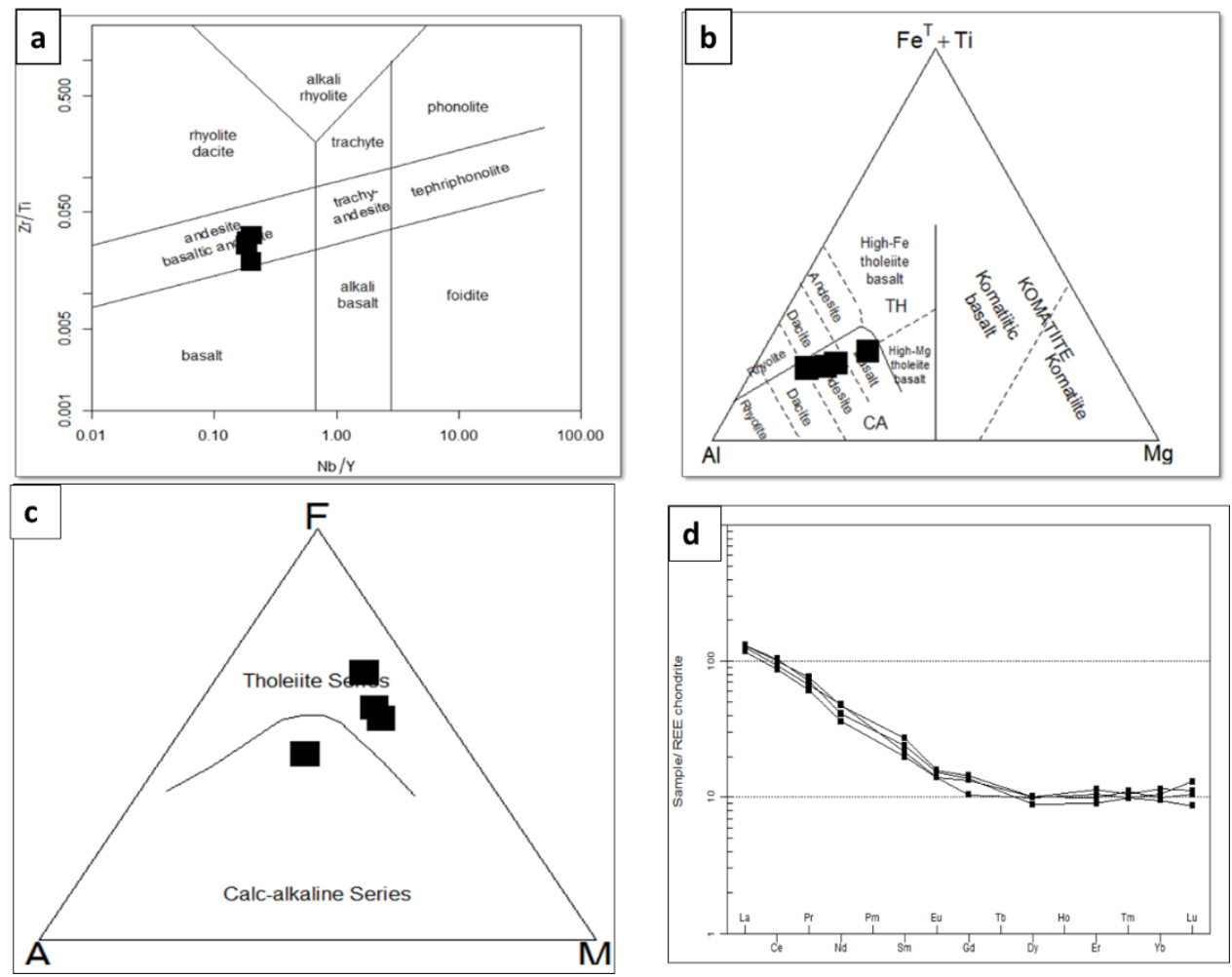

Fig. 8. Discrimination diagrams (a) Zr/Ti against Nb/Y (after Pearce, 1996); (b) Al-FeT+Ti-Mg (after Jensen, 1976) (c) AFM (Irvine and Baragar, 1971) showed the amphibolites are mostly tholeiitic character and (d) Chondrite normalized REE pattern for the amphibolites in the study area.
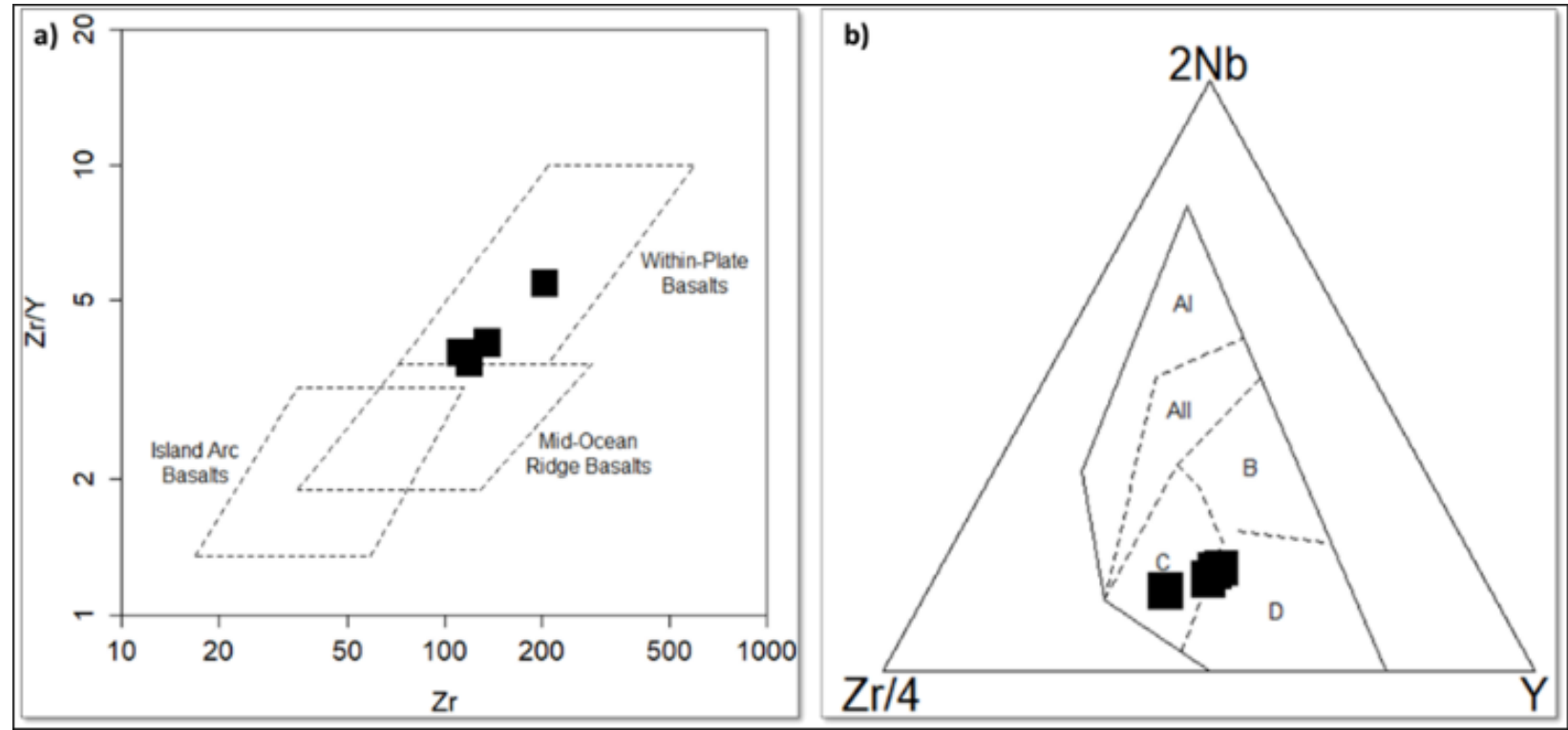

Fig. 9. (a) Zr-Zr/Y classification diagram (after Pearce and Norry 1979) and (b) Zr-Nb-Y discrimination diagram (Meschede 1986) showing the dominance of VAB- NMORB composition of the amphibolites AI-AII. Within-plate alkali basalt and within Plate tholeiites; B. E type MORB; C. Within Plate tholeiites and volcanic-arc basalt; D. N-MORB and volcanic-arc basalt.

\section{CONCLUSION}

The amphibolites within the Iseyin-Oyan schist belt around Itasa area occur as lenses of small to large rocky boulders within quartz mica schist. The amphibolites are dominated by magnesio-hornblende and plagioclase of andesine to anorthite composition with minor minerals including quartz, epidote, titanite, zircon and apatite. Chemical data, Niggli variables and discrimination plots indicated that the protolith are basalt to basaltic- andesite with tholeiitic affinity. Trace and rare element composition suggested that they had suffered crustal contamination, such that they no longer showed the normal positive Eu anomaly characteristics of basic-ultrabasic igneous protolith.

\section{ACKNOWLEDGMENT}

This publication is part of the Ph.D. thesis of the first author, funded by the African Union through the Pan-African University institute of life and earth sciences (including health and agriculture), University of Ibadan, Nigeria. Reviewers are highly appreciated for their comments and criticisms towards the improvement of this paper. 


\section{REFERENCES}

[1] E. N. Ugwuonah, T. Tsunogae and S. C. Obiora, "Metamorphic P-T evolution of garnet-staurolite-biotite pelitic schist and amphibolite from Keffi, north-central Nigeria: Geothermobarometry, mineral equilibrium modeling and P-T path," Journal of African Earth Sciences, pp. 1-15, 2017.

[2] A. O. Oyinloye, "Geology, geochemistry and origin of the banded and granite gneisses in the basement complex of the llesha area, southwestern Nigeria," Journal of African Earth Sciences, vol. 26, pp. 633-641, 1998.

[3] A. O. Oyinloye, "Geology and Geotectonic Setting of the Basement Complex Rocks in South Western Nigeria: Implications on Provenance and Evolution," in Earth and Environmental Sciences, D. I. A. Dar, Ed., Croatia, InTech Europe, 2011, pp. 97-118.

[4] R. Caby and J. Boesse, "Pan-African nappe system in southwest Nigeria: the Ife-llesha schist belt," Journal of African Earth Sciences,, vol. 33 , no. 2, pp. 211-225, 2001.

[5] S. C. Obiora, Field Descriptions of Hard Rocks, With Examples from the Nigerian Basement Complex, M e*d., Enugu: SNAAP Press (Nig.) Ltd.,, 2005.

[6] M. Woakes, M. Rahaman and A. and Ajibade, "Some metallogenic features of the Nigerian Basement," Journal of African Earth Sciences, vol. 6, pp. 655-664, 1987.

[7] NGSA, "Geological map of Nigeria," Nigeria Geological Survey Agency (NGSA), Kaduna, 2011.

[8] M. A. Olade and A. A. Elueze, "Petrochemistry Of The Ilesha Amphibolites And Precambrian Crustal Evolution In The Pan-African Domain Of Southwest Nigeria," Precambrian Research, vol. 8, pp. 303--318, 1979.

[9] S. B. Olobaniyi, "Mineral chemistry and metamorphic cconditions of Isanlu Amphibolites, Southwest Nigeria," European journal of Scientific Research, vol. 13, no. 1, pp. 119-131, 2006.

[10] NIMET, "Weather Report Bulletin," Nigerian Meteorological Agency, Nigeria, 2009.

[11] W. Zhang, Z. Hu, Y. Liu, H. Chen, S. Gao and R. M. Gaschnig, "Total Rock Dissolution Using Ammonium Bifluoride (NH4HF2) in ScrewTop Teflon Vials: A New Development in Open-Vessel Digestion," Analytical Chemistry, Vols. 84,, pp. 10686-10693, 2012.

[12] B. E. Leake, "The Chemical Distinction Between Ortho- and Paraamphibolites," Journal of Petrology, pp. 238-254, 1964.

[13] J. A. Pearce, "A user's guide to basalt discrimination diagrams," in Trace Element Geochemistry of Volcanic Rocks: Applications for Massive Sulphide Exploration, D. A. Wyman, Ed., Canada, Geological Association of Canada, Short Course Notes 12, 1996, pp. 79-113.

[14] L. S. Jensen, A new cation plot for classifying subalkalic volcanic rocks, Ontario: Ontario Division of Mines Miscelleneous Paper, 1976.

[15] T. M. Irvine and W. R. Baragar, "A guide to the chemical classification of common volcanic rocks.," Canadian Journal of Earth Sciences, vol. 8, pp. 523-548, 1971.

[16] U. A. Danbatta and M. L. Garba, "Geochemistry and Petrogenesis of Precambrian amphibolites in the Zuru Schist Belt, Northwestern Nigeria," Journal of Mining and Geology, vol. 43, p. 23 - 30, 2007.

[17] V. Ukaegbu and F. Beka, "Trace and rare-earth element geochemistry: A tool for petrogenetic and geotectonic modeling of ensimatic orthoamphibolites from Pan-African belt of Obudu Plateau, Southeastern Nigeria," Chinese Journal of Geochemistry, vol. 28, p. 019-027, 2009.

[18] T. R. Ajayi, "On the origin and geochemistry of amphibolites of IfeIlesha area, Southwestern Nigeria.," Journal of Mining and Geology, vol. 17, pp. 170-195, 1980.

[19] O. A. OlaOlorun, A. O. Oyinloye and A. R. Adeleye, "Geochemistry and Petrology of Guguruji Amphibolites from Egbe-Isanlu Schist Belt, Southwestern Nigeria," Geosciences, vol. 8, pp. 14-20, 2018.

[20] A. E. J. Engel, C. C. Engel and R. G. Havens, "Chemical characteristics of oceanic basalts and the upper mantle," Geological Society of America Bulletin, vol. 76, pp. 719-734, 1965.
[21] W. V. Boynton, "Cosmochemistry of the rare earth elements: meteorite studies," in Rare Earth Element Geochemistry, P. Henderson, Ed., Amsterdam, Elsevier, 1984, pp. 63-114.

[22] J. A. Pearce and M. J. Norry, "Petrogenetic implications of Ti, Zr, Y, and $\mathrm{Nb}$ variations in volcanic rocks," Contribution of Mineral Petrologists, vol. 69, pp. 33-47, 1979.

[23] M. Meschede, "A method of discriminating between different types of mid-ocean ridge basalts and continental tholeiites with the $\mathrm{Nb}-\mathrm{Zr}-\mathrm{Y}$ diagram.," Chemical Geology, vol. 56, pp. 207-218, 1986. 